\title{
Rural Development: The Case Of Canadian, Texas
}

Neil Terry, West Texas A\&M University, USA

Rex Pjesky, West Texas A\&M University, USA

De'Arno De'Armond, West Texas A\&M University, USA

\begin{abstract}
Canadian is a small town in the northeast Texas Panhandle that is extremely vital and thriving. Although it enjoys large benefits from its oil and gas industry and has some unique qualities in its history that have aided in its success, it is almost a textbook example of rural development success. This case will compare the practices of Canadian to the standards of the literature in rural development and discuss it within the context of that literature.
\end{abstract}

Keywords: Economic Growth; Natural Resources; Regional Economics; Rural Development

\section{INTRODUCTION}

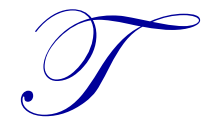

amera sits in her office chair and looks at the family photo on the wall. Born and raised in the region, she recently returned to the rural city of Canadian, Texas as the Canadian-Hemphill County Economic Development Director. Although excited about the new job, Tamera understands she faces many challenges. She believes Canadian is a wonderful place to work and raise a family, but the geographically isolated population of approximately 2,500 has a limited number of opportunities. She wonders if small cities like Canadian can survive and thrive in the modern world or face an inevitable destiny of blowing away in the West Texas wind.

\section{RURAL DEVELOPMENT BACKGROUND}

For decades, rural communities have been in decline. New technology, globalization, and demographic forces that have undercut traditional industries are factors that have contributed to the decline of rural economies. Historically, agriculture has usually been a key to regional economies and rural communities. More recently, manufacturing has provided a second vital component to the prosperity of rural economies. However, globalization has given small towns in the U.S. aggressive competition. During previous generations, manufactured goods produced in rural America found places in markets around the world and those markets have now found cheaper sources of goods from China and other developing nations around the world.

Interestingly, the prosperity of U.S. agriculture has facilitated the decline of rural America. For the past several generations, there has been a virtuous cycle in U.S. agricultural production. This cycle includes a partnership between academic and extension research at major universities, the U.S. government, and farmers themselves. Researchers roll out new technologies that increase yields and mitigate the effects of weather and pests that plague agriculture. The U.S. government's policies of the last century have largely funded these scientific advances and have, with price supports, crop insurance programs, and other farm policies, taken the risk out of production agriculture (Rivoli, 2009).

A key point, from a rural development perspective, is that the virtuous cycle has transformed agricultural production from a very labor-intensive activity into a very capital-intensive activity. This transformation has been a boon for individual farmers as they have seen their yields and profits skyrocket while their risk and physical labor plummet. However, this has not been a boon, necessarily, for small rural communities. As agricultural production needed less labor, the economy provided opportunities for the youth of rural communities elsewhere in other fields 
than agriculture. The decrease in labor intensity of agricultural production, along with similar processes in manufacturing, has caused a decline in population in small rural communities. This decline in population has also made many traditional main street-type businesses disappear. As towns get smaller, they lose the economies of scale needed to make many businesses profitable. Furthermore, the out migration of population leaves fewer people to envision solutions for those who are left. One of the keys to community survival is the ability of communities to grow new generations of leaders (Heartland Center for Leadership Development, 2009). As population sags, the pool from which to draw those new leaders gets smaller.

Entrepreneurship is an important vehicle for future prosperity in rural communities. The challenge of declining population, globalization and other massive economic changes can be seen as potential opportunities. Instead of relying on basic manufacturing and basic commodity agriculture, people in rural communities need to find niche products. These products will stem from the creation of specialized agricultural food products, the producing of advanced manufacturing goods, and provisioning of specialized services, such as the development of unique tourism opportunities specific to a given region. To make this happen, community leaders and rural entrepreneurs must transform their worldview. Instead of thinking solely about community economies, leaders must start their frame of reference on regional economies. Instead of trying to become independent, rural communities must seek ways to become interdependent with their region (Drabenstott, 2003), then find and exploit a competitive advantage, which is an economic niche that aligns regional strengths with market opportunities.

Another strategy for economic development is industrial recruitment, often viewed as a mistake, especially for smaller rural communities (Drabenstott, 2003). The primary problem is that industrial recruitment is expensive. After the massive tax expenditures needed in the form of incentives and the massive direct expenditures needed for public infrastructure surrounding an industrial complex are deployed, the development might not be worth it. Second, industry is often very fickle. A community can lose a major employer as quickly as it can gain one. Stories abound about smaller communities quickly dying after a major employer relocates to another more attractive place. Finally, this type of industrial recruitment is often a zero-sum game where the gain in one region is a loss to another (Rogers \& Ellis, 2000). Still, as Drabenstott (2003) explains, industrial recruitment is a strategy that many rural communities have a hard time abandoning. Yet the new thinking on rural development is to pour resources into developing the entrepreneurship needed to exploit the community's natural strengths.

The consensus of the literature is that in order to survive, a community must integrate into its region, use entrepreneurship to exploit competitive advantage, and effectively train a new generation of leaders. Canadian, Texas has all the signs of a successful, vital community.

\section{CANADIAN, TEXAS OVERVIEW}

Although one can trace the history of Canadian back nearly 1,000 years, the contemporary history of the region starts when the first cattle ranchers arrived in the 1860 's. The 1880 census counted 9,600 cattle and only 149 people in Hemphill County. Canadian officially became a town in 1888, soon after construction of the Santa Fe railroad in the area. Railroad workers and the saloon operators that serviced them originally dominated the population of Canadian, but very soon the WTCU (Women's Christian Temperance Union) helped the transition from boomtown to hometown (Canadian Chamber of Commerce, 2010) by establishing elements of civil society in town. By 1900, the county's population had grown to 815 people. Ranching continued to be the primary activity in Canadian (the dust bowl knocked out a small farming sector of the local economy) until the 1950s when technology was developed to access the deep oil and gas reserves below the Canadian topsoil. Since the 1950s, the overall economic health of the Canadian area has aligned with the state of the oil and gas industry, which includes periods of both booms and busts. Today, Canadian's population is slightly under 2,500, the median age in 37.7 years old, and estimated median household income is $\$ 57,822$, which compares favorably to the Texas average of $\$ 48,259$ (City-Data.com, 2010).

A vital key in rural development is finding a competitive niche for the region. Gone are the days where a small community can thrive by producing basic agricultural commodities and generic simple manufactured goods. A region must find a competitive niche of products or services for export beyond the internal community. Exporting specific, unique goods or services is important in that it helps the community become interdependent on the world 
around them (Drabenstott, 2003). Canadian, although small, is successfully pursuing several niche industries at once. First, it is rich in minerals. Although they are basic commodities, oil and gas production does provide for significant wealth creation. Canadian's second niche is tourism. Canadian's geography is perhaps unique for the Texas Panhandle. People recognize the Texas Panhandle, western Oklahoma, and southwest Kansas for its flat, semi-arid geography. The immediate Canadian area deviates from that considerably. There are rolling, rocky hills, a few small lakes and the major Canadian river. These geographical features create opportunities for outdoor activities and events of which Canadian has many.

When a community recognizes its competitive niche, it must identify and develop the necessary secondary firms to support the primary firms and improve and leverage local amenities (Drabenstott, 2003). Canadian's primary niche, other than the obvious mineral and agricultural opportunities, seems to be tourism. The area's unique geographical and historic features in the middle of a semi-arid desert give it a unique opportunity to follow their self-promoting title, "The oasis of the Panhandle". Canadian has developed its local amenities and secondary firms to support a primary mission to develop tourism. To have a successful tourism industry, a place must have activities. The area around Lake Marvin and the Canadian River provide opportunity for outdoor activities. In addition, the town presents a Fall Foliage Festival (unique on the high plains of Texas), tours to see the spring lesser prairie chicken, a rodeo, and several other events. Visitors can also visit the town's art museums, antique shops, eat in a variety of restaurants, and visit Canadian's city parks. Options for lodging include hotels, motels, bed \& breakfast lodgings, RV facilities, and open area camping.

There is reality in Canadian's history that may have led to its current ability to revitalize itself. Early in its history, the settlers of Canadian were ranchers instead of farmers (Canadian Chamber of Commerce, 2010). Ranching, as opposed to farming, led to a concentration of wealth in the hands of a few ranching families. One of these families was the Moody family. Robert Moody was a local rancher who built the Moody Hotel in downtown Canadian. The hotel was built both as a symbol of hope in the future of the community's prosperity and as a mechanism to bring prosperity to Canadian. The concentration of wealth that came from ranching resulted in individuals with the ability to make massive per capita investments in the community. Contrast this ability to make large community level private investments with the reality of many other communities that were based on farming. Farming was an activity that led to a relatively equal distribution of wealth. Although farming was able to produce wealth, none of that wealth concentrated enough to make transformational investments, like the Moody Hotel, possible. Early in its history, and even today, Canadian has had people who had the means and ability to make massive investments in Canadian's future. These individuals made these investments because they believe in the future of the community and believe that these large investments can make that bright future inevitable.

\section{TENENTS FOR RURAL ECONOMIC DEVELOPMENT}

Brown-Graham and Lambe (2008) offer four tenets for rural economic development in the new economy. The first tenet is to increase innovation with modern technology and human capital that can effectively deploy the technology. Competitive rural communities must simultaneously prepare themselves for new-economy jobs while also strengthening their traditional bases. Innovators need to help existing enterprises differentiate their products through product design, production speed, logistics, the end-user experience, or superior marketing. For rural firms to survive their strategies should include business incubators, organized industry networks, and brokers operating between businesses and sources of specialized technical assistance. To capitalize on the new economy, communities must build the organizational capacity of education and training institutions, provide opportunities for on-the-job training, and foster mentoring at all levels. In addition, residents must have access to technology. Despite incredible growth in personal computer ownership and Internet access, many rural areas face distinct technological literacy and access shortcomings. Combining development services with workforce training can have a significant impact on the stability and expansion of local innovation in rural areas.

The second tenet of rural economic development put forth by Brown-Graham and Lambe (2008) focuses on capital investments in people, products, and places. Putting innovations to use almost always requires capital investment in the community's infrastructure, which includes roads, water, sewer, telecommunications, and educational institutions. Encouraging the existing private market to make financial capital available and create alternatives to the private market are two approaches to increasing access to capital in a community. The primary 
regulatory avenue to increasing access to capital in underserved communities is the federal Community Reinvestment Act (CRA). Special savings accounts, tax credits, and public venture funds are other sources of private financing in rural areas. A very important start to revitalizing and ensuring the survival of a local rural region is to build a home for the regional partnership. Whether considering a developing nation or the revitalization of a rural region in the United States, institutions matter. In order for private or public investment to succeed, there must be appropriate institutions suitable for growth and development in place. Communities that pursue a purposeful developmental strategy and take the effort to build institutions to support those strategies tend to achieve higher economic growth than other communities (Drabenstott, 2003).

The third economic tenet for rural economic development focuses on natural resources and preservation. Natural resources, like oil and gas, have always been vehicles for economic development, but quality of life factors are increasingly important for stimulating private investment. Rural America has benefited as retirees and others escape the downside of urban living. Conserving an area's natural capital takes on additional significance for rural America in many locations. In many places, the trend is for the replacement of family farms by large-scale meat, poultry and dairy processors that create jobs but generate enormous amounts of concentrated wastes. Recreation communities, lakes, rivers, forests, and other wildlife habitats may face environmental concerns from increased use. Creative local development might involve investing in projects that preserve and connect natural areas like greenways, waterways, wildlife habitats, parks and open spaces in ways that support a community's quality of life without negating other economic development opportunities.

The fourth tenet of economic development recognizes the social and physical components in economic relationships. Such social connections refer to relations among individuals, organizations, communities, and other social units that result in tangible economic benefits. People in communities endowed with a rich stock of social networks are in a stronger position to develop the capacity to address the problems of poverty, to rebuild their communities, and to achieve a measure of control over their lives (Warren, 2001). Within economies, social networks provide access to critical supports. A young mother may depend on social relationships to find childcare while she works, an aspiring entrepreneur may rely on a relationship with a community development financial institution to secure a first loan, or a company may leverage a relationship with one of its suppliers to expand its business venture (Brown-Graham and Lambe, 2008). However, the geography of rural places provides unique challenges in creating and maintaining these dense social networks. Social connections in rural places must be on linking people, businesses, and institutions to wider regional economic networks and opportunities. As a practical matter, rural connections must also be physical. If rural communities are to leverage their connections to their neighbors and the world, they must connect by roads, rail, airports and communication channels. Rural areas in proximity to urban areas and those in proximity to small towns already experience greater growth than those in more remote areas.

\section{CASE QUESTIONS FOR CLASS DISCUSSION}

What actions should a rural community like Canadian, Texas take in order to achieve economic growth and maintain viability as a small city? There are no explicit answers to the Canadian case, but there are several points worthy of discussion in an undergraduate public finance, economic development or microeconomic theory course. Before reading the epilogue to find out how Canadian approached the issue, discuss the following questions:

1. What strategies can a rural community in your region employ to facilitate economic development via the diffusion of technology?

2. What are the opportunities versus challenges associated with a rural community making capital investments in people, products, and places?

3. Critics argue that a strategy of tying development with preservation and recreation is not sustainable. What are the strengths and weaknesses of the criticism? Can a rural community preserve the natural environment and simultaneously create a diverse economy with multiple employment opportunities?

4. How can a rural community in your region develop the social and physical components in economic relationships that foster economic growth? 
5. Assume in her role as Canadian-Hemphill County Economic Development Director, Tamera is asked to identify two specific objectives as focus points for economic growth in Canadian for the next five years. What do you believe are the two things she should select?

\section{EPILOGUE}

The economic development of Canadian, Texas has followed a path that is more successful than most other rural cities. The existence of oil and gas wealth certainly enriches the community in a way that is not possible for many other rural communities. Beyond oil and gas revenue, Canadian has participated in multiple efforts that cross all four economic development tenets discussed in previous sections. This section offers case resolution with a brief review of specific efforts put forth by business and economic stakeholders in Canadian.

The most significant effort in Canadian relating to the innovation and technology tenet is gaining direct access to a T1 fiber optic line that can carry over 60 times more data than a normal residential modem. Funding for the T1 line is by a rural fee surcharge added on telephone bills as part of an effort to make certain rural communities part of the information super highway. Canadian was one of the first rural communities to take advantage of the rural fees for the T1 telecommunications initiative. One immediate result of the effort supported the Abraham Trading Company. The Abraham Trading Company employs 15 people in Canadian with a focus on trading futures markets around the world. Part of a Barron's feature in 2012, Abraham Trading Company has approximately $\$ 600$ million in capital under management (Smith, 2012). The company would normally be located in a downtown office in Dallas or New York, but the telecommunications infrastructure makes it possible to function without problem in Canadian.

Capital investment in people, products, and places is also part of economic development in Canadian. The citizens have consistently invested in the city infrastructure, which goes back to the early days of ranching heritage and the construction of the Moody Hotel in 1910, which was the first fireproof hotel in the Texas Panhandle. Oil and gas revenue is a key to financial success in the city of Canadian. Although subject to booms and busts, oil and gas has created a steady stream of revenue for the city and school district. The Canadian Independent School District normally sends over $60 \%$ of educational income to the state capitol in Austin for redistribution as part of the state Robin Hood plan of redistributing funds from wealthy school districts to poorer school districts. Despite the large outflow, Canadian has the financial base to invest in schools and training. Approximately $90 \%$ of recent tax base comes from oil and gas, which helps the city create an annual budget over $\$ 500,000$ a year to support economic development efforts. The banking and finance sector of Canadian is supported by a robust offering of three regional banks and a credit union.

Despite access to financial services combined with general prosperity, housing is one of the major limitations in Canadian. In general, land in Canadian is concentrated in the hands of a few families and has rarely been available for sale and development. Short-run population booms correlated with expansion of the oil and gas industry have resulted in a relatively high number of hotels and motels per capita but not a large number of new housing units. In recent years, Canadian has sought to expand both high income and lower income housing options. A private development effort on the Southern part of the city could add as many as 100 new middle and highincome households. In addition, the city has been involved in the pursuit of a tax credit program through the IRS to support developers interested in creating low-income housing. Despite the efforts to increase housing options, city leaders have a limited desire to fix the low population problem and prefer more of a focus on amenities and qualityof-life considerations. Ideally, there is a desire to reach a stable population of 3,000 to 3,500 residents to help create and support a more robust retail sector, but there is not a desire to achieve a large-scale increase in population.

Natural resources and preservation are an important part of the Canadian economic development strategy. The oil and gas industry is the lifeblood of the city, but recent efforts have focused on diversifying the city economy in order to minimize the impact of industry downturns. Ranching and financial services are established industries in the region, but the emerging efforts tend to focus community development on tourism, including nature tourism. Tours include options to observe the lesser prairie chicken, which was the inspiration for an eco-tourism option. Lake Marvin, the Canadian River Walking Bridge, the Black Kettle Nation Grasslands and the Gene Howe Wildlife Management Area are other major eco-tourism options available in the Canadian area. The Fall Foliage Festival, 
guided nature tours, and live falcon demonstrations are some of the more successful eco-tourism efforts by a rural community. The festival drawing power reaches approximately 10,000 people over a scheduled, highly promoted weekend in October and accounts for $25 \%$ of annual revenue for several retail firms. Beyond tourism, Canadian and the surrounding areas are involved in natural resource development such as wind energy and water rights.

One of the strengths of many rural communities is the establishment of strong social connections. Canadian is a city that has been very active with both private and city efforts to facilitate social connections. The heritage of a ranching culture with money concentrated in the hands of a few families initiated a spirit of private investment into the community over the years. Private and local government funding has resulted in a recent remodel of the downtown area, which includes the $\$ 1$ million renovation of the Palace Theatre by a local businessperson. The renovation project was completed expeditiously so that the design of the theater and the uses of the adjacent retail spaces could be developed uniformly. The Palace Theater has a visual digital projection system that is one of only 300 in the world. It is also the only THX-approved theatre in the Texas Panhandle. Since the completion of the Palace Theater, the areas along Canadian's Main Street have evolved to include a deli/soda fountain, an art gallery, and a new steak house. The Texas Department of Transportation has agreed to spend $\$ 2.2$ million in the city to return the state highway into a brick street with modern sidewalks, historic representation lighting, and underground utilities. The vision for creating a wonderful cinema environment for the people of the northeastern Panhandle area has broadened into the rehabilitation of an entire town. Other area attractions include Aud the 50-foot dinosaur, the River Valley Pioneer Museum, Texas Crown Performance Hall, the Canadian River Art Western Gallery, and The Citadelle Art Foundation, which features the works of Norman Rockwell and Sir Thomas Lawrence. The renovation of the Main Street area supported with an injection of private funds and the creation of a private museum with works from internationally recognized artists is representative of the community support of the city of Canadian. It is a place where people care about the present and future of the city. People tend to know and support one another via various formal and informal social interactions.

The physical network for Canadian is dominated by the proximity to Amarillo, Texas. The Amarillo area is a community of approximately 250,000 people and serves as the regional hub for retail, travel, and entertainment. Canadian is approximately 100 miles away from Amarillo, which is close enough to take advantage of some of the offerings from the larger city but far enough away to maintain a high degree of independence.

The people of Canadian have worked hard to reconcile their economic goals, rich history, unique culture and quality of life. Today, citizens look forward to a future that preserves a hometown they love and conserves a natural setting they cherish and share with the birds and wildlife. They put as much time and thought into questions of developing water and wind energy plans, development and housing challenges, education and work force training as their ancestors did, and are determined not to be the last generation in the remote, romantic Canadian River Valley (Canadian Texas Chamber of Commerce, 2010).

\section{AUTHOR INFORMATION}

Dr. Neil Terry is dean and professor of economics at West Texas A\&M University in Canyon, Texas. Dr. Terry earned a doctorate degree in economics from Texas Tech University. E-mail: nterry@wtamu.edu (Corresponding author)

Dr. Rex Pjesky is associate professor of economics at West Texas A\&M University in Canyon, Texas. Dr. Pjesky earned a doctorate degree in economics from Oklahoma University. E-mail: rpjesky@wtamu.edu

Dr. De'Arno De'Armond is the Hickman Professor of Marketing at West Texas A\&M University in Canyon, Texas. Dr. De'Armond earned a doctorate degree in financial planning from Texas Tech University. E-mail: ddearmond@wtamu.edu

\section{REFERENCES}

1. Brown-Graham, A. \& Lambe, W. (2008). Four tenets for rural economic development in the new economy. Carsey Institute Policy Brief, 9, 1-8. 
2. Canadian Chamber of Commerce (2010). Canadian, Texas: Wildlife, History, and Tradition. Retrieved April 15, 2012, from http://www.canadiantx.org/history.html

3. City-Data.com (2010). Data for Canadian, Texas. Retrieved April 15, 2012, from http://www.citydata.com/city/Canadian-Texas.html

4. Drabenstott, M. (2003). A new era for rural policy. Kansas City Federal Reserve Economic Review, 4, 8198.

5. Heartland Center for Leadership Development (2009). Clues to rural community survival. Retrieved April 15, 2012, from http://heartlandleadership.blogspot.com/2009/01/new-edition-of-clues-to-ruralcommunity.html

6. Rivoli, P. (2009). The travels of a t-shirt in the global economy: An economist examines the markets, power and politics of world trade $\left(2^{\text {nd }}\right.$ ed.). Hoboken, New Jersey: John Wiley and Sons.

7. Rogers, C. \& Ellis, S. (2000). Local economic development as a prisoners' dilemma: The role of business climate. Review of Regional Studies, 30(3), 315-330.

8. Smith, N. (2012, May 26). An unfamiliar territory: How managed-futures trader Salem Abraham plans to end his recent losing streak. Barron's on the web. Retrieved July 10, 2012, from http://online.barrons.com/article/SB50001424053111903964304577418303932326824.html

9. Warren, M. (2001). The role of social capital in combating poverty. Susan Saegert (Ed). Social capital and poor communities, New York: Sage Foundation. 


\section{NOTES}

